\title{
Why we still need collections - Museums in the business of originality
}

Pourquoi nous avons encore besoin des collections - Les musées dans l'affaire de l'originalité

\section{Nina Robbins}

\section{(2) OpenEdition}

\section{Journals}

Electronic version

URL: http://journals.openedition.org/iss/2210

DOI: $10.4000 /$ iss. 2210

ISSN: 2306-4161

\section{Publisher}

ICOM - International Council of Museums

\section{Printed version}

Date of publication: 1 August 2020

Number of pages: 183-192

ISBN: 978-2-491997-11-3

ISSN: 2309-1290

\section{Electronic reference}

Nina Robbins, "Why we still need collections - Museums in the business of originality », ICOFOM

Study Series [Online], 48-1 | 2020, Online since 01 August 2020, connection on 08 August 2020. URL : http://journals.openedition.org/iss/2210 ; DOl : https://doi.org/10.4000/iss.2210 


\section{Why we still need collections - Museums in the business of originality}

\section{Nina Robbins}

University of Helsinki - Helsinki, Finland

\section{A BSTRACT}

This article examines how museological value discussion can offer a tool for museum professionals to engage themselves in the current discourse regarding building sustainable futures. In this work, it will be essential to consider the long line of museological traditions, and not rely only on current trends. The development of values cannot reach a culmination point in the span of just one museum career. Such values are rather developed over the centuries. This can be seen in objects that have received key object status in museum collections. The concept of object energy is introduced to emphasize the need for a deeper view and a longer perspective. Eventually, this discussion could resonate well with the current global demands for a more sustainable future, thus putting museums in the position of being strong policy makers in society in general.

Keywords: Museology, value discussion, theory, object energy 


\section{Pourquoi nous avons encore besoin des collections - Les musées dans l'affaires de l'originalité}

Cet article explique en quoi le débat autour des valeurs de la muséologie peut constituer un outil permettant aux professionnels des musées de s'engager dans le discours actuel sur la construction d'un développement durable. Dans ce but, il est essentiel de considérer au long cours la tradition muséologique et de ne pas se fier uniquement aux tendances actuelles. Les valeurs ne peuvent pas être élaborées au cours d'une carrière dans un musée, mais sont accumulées siècle après siècle. Cela se voit dans les objets clés des collections du musée. Le concept d'énergie d'objet est introduit pour souligner la nécessité d'une approche en profondeur sur une perspective plus longue. Finalement, cette discussion entre bien en résonance avec la demande mondiale actuelle pour un développement durable, faisant ainsi des musées des acteurs politiques puissants au cœur de la société.

Mots-clés : muséologie, discussion de valeurs, théorie, énergie d’objet

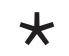

The Kyoto 20I9 Conference gathered a large cross-section of museum professionals, discussing matters near and dear to them. Certainly, the conference will be remembered for its vivid discussion regarding the new museum definition, but a number of other issues were raised as well (ICOM Kyoto, 2019). In the ICOFOM sessions, an important issue about the future direction of museological theory formation was raised (Mairesse, 2019a). In addition, new ideas, intended to supersede old ways of thinking, were also sought (van Mensch, 2019). This one-week conference was a fruitful time for gathering ideas and taking part in discussions, in order to map and point out matters of significance in the field of cultural heritage. In my short article, I will present one potential way of thinking about our field; the discussions in Kyoto were my initial inspiration. In my text, I will look at questions, such as the direction of museological theory and the desire to go beyond current thought, but ultimately, I will try to build on existing museological legacy, taking that as a solid starting point. There is no need to undo what has already been done; it will be more fruitful to ascertain the relevant aspects of existing theory and integrate them into any new network of thoughts.

In recent decades museological theory building has been intrigued by such concepts as researching museum value (Holden, 2006; Scott, 2013), measuring significance (Russell \& Winkworth, 2009; Häyhä \& Jantunen \& Paaskoski, 
20I5) and pointing out key objects in our cultural biography (van Mensch \& Meijer-van Mensch, 20II; Lehto-Vahtera, 20I8). In addition, newer ideas of audience engagement and aspects of co-creation have further democratized the role of professionals and introduced a new group of stakeholders to participate in content planning (Anderson, 2004; Simon, 2010). All these concepts ought to be synchronized with the global responsibilities of institutions that have solidified their roles as part of society builders (Museoalan Teemapäivät 2019). In this respect, museums are strong policy makers in society and this role should not be subsumed within the traditional identity of museums as mere keepers of the past.

If we accept the claim that museums are indeed policy makers, we as museum professionals will need tools in order to navigate in the world of such policymaking. One path to unravel this toolbox will be to look at the value processes of society - how values are created and who gets to advocate for them. It is important to implement the relevant vocabulary, express matters of significance and eventually get an invitation to voice all of this in policy-making discussions.

This is an article of an overview and it is strongly connected to my Kyoto pre-conference paper "Museological Value Discussion - A Tool to Transfer Tradition to the Future", where I described the need for a long-term perspective to be included in the value building of museum identities (Robbins 2orga). Only with such a long-term perspective can museums show the aggregation of various impacts and differentiate themselves in the contemporary impact race (Vaikuttavuusindikaattorit, 2009). This text is a continuation of this theme and focuses on concepts such as the significance of humanistic disciplines in the economic realm. It points out how we, as observers of history and tradition, can understand original objects in our Great Museum, as described by museologist Kenneth Hudson (1993), possessing an aura that eventually results in a whole that is greater than the sum of its parts. The text does not aim to focus on details but tries to show similarities in thought building among various disciplines. "Interdisciplinary" might well be the best term to describe these connections, which show the interchange among fields of philosophy, art history and museology, perhaps inspiring experts to further their theory building in the field of museology. Why do we as museum professionals have the right to make decisions about collection destinies? Why are collections still relevant, and why we do still want to hold collections so near and dear? The chosen interdisciplinary approach will help to answer these questions.

\section{Legitimacy in the great cultural biography}

To start building on the legacy of safekeeping requires knowledge about the path that individual collection items might have travelled throughout the centuries. This requires trust in the fact that there has been some kind of meaning attached to these objects in order for them to have survived. An assembly of collected objects has been regarded as the core of museums ever since the time of the first encyclopedias, which offered guidance on how to 
organize such assemblies of objects (Impey \& MacGregor, 1985). Cabinets of curiosities were seen as signs of wealth, knowledge and power. Eventually, the collecting of various objects became more and more systematic and European courts and rulers became more and more knowledgeable regarding the thoughts of the Enlightenment. As a result, the idea of collections became part of the public domain and spread throughout Europe (Pearce, 1990; 1992). The 19th century was the great era of museums. These new institutions were seen as public entities, offering an educational niche in society and holding collections in trust for society (Fox, 2018). Already in the late i8th century, museums such as the British Museum or the Louvre, were definitely beacons that paved the way for other great European museums. This work was the foundation for museum identity building, which eventually can be seen in the $2 \mathrm{I}^{\mathrm{st}}$ century museum projects that integrated community empowerment (Simon 2010; Filene, 2019). The demands for a more democratizing museum environment have also produced thoughts of self-reflection and demands for a shift in focus (Anderson, 2004; Conn, 2010). As a result, current museums need to be more aware of their operating environment and need to invite the voices of various groups and communities in generating a contemporary light that can shine along with historical beacons. It is a long path, and the meaning of collecting has been at the center of this legacy. Professor of Museology Janne Vilkuna (2003, p.ro) from Jyväskylä University commented, "Professionalism related to research and preservation work of the current museum generation will greatly determine what kind of past we will have in the future." In this context, it is easy to see that museum professionals are mediators in a long and ongoing process of creating meaning.

In order to give legitimacy to museum professionals in their work as advocates of our heritage, we need to look into philosophy. American philosopher George Dickie's concept of the Institutional Art Theory will offer us one point of departure. No doubt, there are many others that we could consider, but his arguments will give us a framework, which will eventually allow further arguments to be considered and developed. Dickie wrote in his book Art and Aesthetics: An Institutional Analysis (1974) about how human beings learn to point out and give value to artistic items only if their surroundings are such that they promote this kind of learning. He used the concept of his fellow philosopher Arthur Danto, calling these surroundings an "Artworld" (Danto, 1964). In short, we need to learn from childhood onward the various things in our artworld that can be called art, distinguishing them from things that are not. According to Dickie, there are people who produce material for our viewing, and this group of people is called "the core produces" of the given artworld. Amongst this group, there are artists, who create objects, and gallery and museum professionals, who evaluate this created material. Once a selection has been made and brought forth for viewing, the "audience" in the artworld has to give the displayed selection their approval. This chain of procedures eventually builds the legitimacy for the material that will ultimately be considered art. This line of thinking can be broadened further to encompass 
entire museum collections, or even the entire realm of our cultural biography, not just artworks of any current period. The number of those people seen as core producers can vary, depending on the perspective. Dickie's institutional art theory gives us a point of departure to start mapping our context and making a claim that museum professionals are the core creators of what kind of heritage our future will have.

In my pre-conference paper (2019a), I introduced the concept of Museological value discussion in order to be able to use the above-mentioned right to make decisions regarding museum collections. Museological value discussion comprehensively takes into account the entire span of everyday museum practices and addresses the need to consider both philosophical and practical approaches. It results in a value network, which consists of selected values, specific to a given museum or heritage organization. This network is not based only on our current idea of values or identity, but also on those that have accumulated over the centuries. This is seen, for example, in the existence, caretaking and research of collections throughout history, and is seen in the obvious key objects of our culture. Through this understanding, museums do not exist only in an isolated past, nor do they have meaning only in our current society. Rather, they carry meaning and understanding from the past to the present and into the future.

This work has to be seen from a comprehensive viewpoint, having its roots in history. It is not only a question of single objects or their significance and key roles as part of a current museum. It is also about the process in which one museum item has to be seen as part of a greater heritological reserve. It is important to see the collections that we have as a reserve, regardless of whose ownership they might be under at any given time in history. The role of museums is to point out significance in this reserve. By studying this, it becomes possible to obtain information about the mutual values among museums and more easily reach a common voice. This common voice is needed in order to see heritologically meaningful aspects of society as more than only possessing market - or profit-oriented values for our current consumption. Museums engaging in museological value discussions is something that resonates well with the current global demands for a sustainable future (Raworth 2017; Mazzucato 2017). In this respect, museums can be strong policy makers in society, showing how the work done in museums has had a long history in helping to create a sustainable future.

\section{Could it be more than just the sum of its parts?}

It is useful to take the demand for museological value discussion a bit further and show concrete ways of how this actually works. I have stated that museology is an excellent example of a discipline that bridges theory and practice. We need to be aware of the theoretical thinking guiding our practical everyday work. My previous research showed that museum professionals in Finland have a lot of knowledge about values related to their collections, but this knowledge has not yet manifested itself to a substantial degree in official forms such as 
strategies, collection policies, articles, exhibitions, etc. (Robbins 2016; 2019b). This has left professionals unaware of their own strengths as policy makers within the field of values. In 20I7, hands-on value workshops and value debates were introduced as part of the museum studies program at Helsinki University. This work aims to prepare future museum professionals to be prepared for value discussions. It is important to inspire students, as well as professionals already working in the field, to actively engage and challenge themselves in value-related discussions. It is essential for them to be fully prepared to justify the importance of their work. Prior research shows that in order for value discussions to result in practical, real-life tools, it is important to achieve a coherent understanding of the value network behind any given actions (Scott, 2013; Holden, 2006). Once the focus of the active value network of one's own museum is clear, museum professionals will be better equipped to respond to any short-term fluctuations in their everyday work. As a result, there will be a more coherent and focused understanding regarding values between and among various parties, be they museum professionals, politicians, students or museum visitors.

As stated before in this article, society in general has given the power to museum professionals to transfer traditions from the past to the future. In this work, we need collections and original museum items in order to do our job properly. This demand is at the core of our mission and a feature that not many other institutions possess. Museums are the holders of original objects, and society has entrusted their care and safekeeping to museum professionals. Object research is an important part of museum work, but as a recent Finnish survey shows, more attention could be paid to it (Artefacta 2016). In general, object research reveals past histories, which are transformed into stories in the hands of museum professionals. But sometimes these original items result in more than just the sum of their researched pasts. This "something more" can be observed in the comments, such as museums objects being of immeasurable value, or collections having obvious key objects. It is almost as if the written information does not quite encompass the entire object's existence. However, is there something more to all of this?

One could look at the issue through the concept of object energy. This concept has been used to describe the written information surrounding an object: "The tales of museums differ from many other tales because they are based on the evidence that objects include, and are transmitting, i.e. object energy." (Vilkuna I997, p. 57). Vilkuna presented this comment in a seminar and this comment related to the stories contained in objects, which could be revealed through research. In addition, the concept of object energy can also be related to information gathered from the materiality of the object. For example, conservators working with collections become very familiar with the material aspects of original museum objects, i.e. tool marks, signs of ageing or changing fashions in materials and their effects on originality. They need to consider an object's materiality and all the written information, as a comprehensive entity, before 
the first stroke of a scalpel or the addition of new material. Indeed, sometimes the existence of these original objects resonates more than what can be gathered from the written documents. It seems that there is more than just the network of documented context information that affects original museum objects. However, how can we describe this process?

Professor Vilkuna attaches object energy to the context, but one can look at object energy also from a more intrinsic point of view. This is understood as an object consisting of something else than just its context. It has originality, marks of usage and an exterior form, but eventually it is something larger than the sum of its parts. Finnish art historian Anne Aurasmaa (2005, p.22) writes about the memory of museums, consisting of both facts and emotions: "Even though the production of factual knowledge on museum objects is at the core of museums' educational duties, it is obvious that we also need sensuousness in order to deeply understand the effects, relationships and values of matters surrounding us." This thought is close to cultural philosopher Walter Benjamin's (1892-1940) line of thinking in his 1936 essay "The Work of Art in the Age of Mechanical Reproduction" regarding the essence of something original. Original items contain something that we cannot explain with science, as they have a unique aura. Acknowledging the fact that Benjamin's concept of an aura being product of its time, we could still relate it to those rare moments when we see something significant being valued in a museum collection. This can hold true whether it is, for example, an old and patched up sweater of a fisherman or a veal skin diving suit donated to a museum collection in the later part of the Igth century. By no means are these items immeasurable in terms of monetary values, but they do possess wear and tear that has been accumulating, thus building their auratic value, i.e. object energy.

Similarly, the need for a sensuous presence could be seen in relation to Benjamin's concept of an aura or the concept of object energy. We need to point out this presence and follow George Dickie's line of thinking, i.e. we need to learn from childhood onward what is significant in our Museumworld. It is clear that these demands for object energy, aura or sensuous presence are not created by the objects themselves, but are rather undocumented and unwritten meanings that we, as observers, have attached to these objects over the centuries. This process is not a phenomenon for one era only but takes time to develop. One generation cannot bring this object energy to any kind of final destination. It is created over time, when the significance of the object is recognized generation after generation.

\section{Impact that matters}

In this article I have taken a broad perspective to describe why we still need collections and have used a very private human condition to back up that claim, namely the concept of object energy of original items in museum collections. Museums are in the business of originality. Certainly, there are various contemporary ways to reflect that importance to audiences, but the original 
museum object should nevertheless remain at the core. Studies have shown that society's institutions have to be able to measure their impact in order to survive in the contemporary impact race (Weil, 2002; Vaikuttavuusindikaattorit (Impact Indicators), 2009; Piekkola, Suojanen \& Vaino, 2013). In these studies, impact is seen from a short-term perspective, with results expected to be seen during the current generation. This is in itself legitimate, but we should also consider a longer lifespan when measuring the impact of object energy, which has been evident ever since the cabinets of curiosities. This can simply be observed in the collection care of museums. In such work, it will be beneficial to join forces with other impact-involved sectors of museums, namely that of conservation. At the Kyoto ICOM Conference, ICOFOM and ICOM-CC organized a joint afternoon session, where museologists and conservators were searching for and finding common ground for future cooperation (Mairesse, 2019b). This will be a fruitful direction to go in the search for determining long-term impact factors. It will be important to join forces and learn to point out the impact of long-term preservation, as well as to show such impact in a historical perspective. This will certainly be a welcomed vocabulary for future impact investors, be they investors in the traditional, economic sense of the word or young humanists who are voicing their opinions outside the humanities.

\section{References}

Anderson, G. (Ed.). (2004). Reinventing the Museum - Historical and Contemporary Perspectives on the Paradigm Shift. Lanham, US: Altamira Press.

Artefacta. (2016, June 22). Konkreettinen esinetutkimus harvinaista. [Concrete Object Research is Rare] Retrieved December 28, 2018 from http://www. artefacta.fi/uutiset/konkreettinen_esinetutkimus_harvinaista.552.news

Conn, S. (2010). Do Museums Still Need Objects? Philadelphia, US: University of Pennsylvania Press.

Danto, A. (1964). The Artworld. Journal of Philosophy, 6I, 57I-584. Retrieved April 3, 2014 from http://www.georgetown.edu/faculty/irvinem/visualarts/danto-artworld.pdf

Dickie, G. (1974). Art and Aesthetics: An Institutional Analysis. New York, US: Cornell University Press.

Filene, B. (Ed.). (2019). Tobe. North Carolina, US: The University of North Carolina Press.

Fox, M. D. (2018). Engines of Culture: Philanthropy and Art Museums. London, UK: Routledge.

Holden, J. (2006). Cultural Value and the Crisis of Legitimacy. London, UK: DEMOS. Retrieved September 8, 2013 from www.demos.co.uk 
Hudson, K. (1993). The Great European Museum. Nordisk Museologi, 1993,2, 51-60.

Häyhä, H., Jantunen, S. \& Paaskoski, L. (2015). Merkitysanalyysimenetelmä [Analysing Significance]. Helsinki, Finland: Suomen Museoliitto.

ICOM Kyoto. (2019). Museums as Cultural Hubs: The Future of Tradition. $25^{\text {th }}$ ICOM General Conference. Kyoto, Japan: ICOM.

Impey, O., \& MacGregor, A. (Eds.). (1985). The Origins of Museums. London, UK: House of Stratus.

Lehto-Vahtera, J. (Ed.). 20I8. Kokoelmien avaimet - Museokokoelmien tunnisteobjekteja. Turku, Finland: Aboa Vetus \& Ars Nova

Mairesse, F. (2019a). Museology as an Intangible Heritage: past, present and future. Session I: The Future of Tradition in Museology. In ICOM Kyoto. Museums as Cultural Hubs: The Future of Tradition. 25 ${ }^{\text {th }}$ ICOM General Conference. Kyoto, Japan: ICOM.

Mairesse, F. (2019b). What is the Essence of Conservation? Session 4. In ICOM Kyoto. Museums as Cultural Hubs: The Future of Tradition. $25^{\text {th }}$ ICOM General Conference. Kyoto, Japan: ICOM.

Mazzucato, M. (2017). The Value of Everything: Making and Taking in the Global Economy. London: Allen Lane Penguin Books.

van Mensch, P, \& Meijer-van Mensch, L. (20II). New Trends in Museology. Celje, SIovenia: Museum of Recent History Celje.

van Mensch, P. (2019). Discussion in Workshop C. Museology, Theory and Practice. In ICOM Kyoto. Museums as Cultural Hubs: The Future of Tradition. $25^{\text {th }}$ ICOM General Conference. Kyoto, Japan: ICOM.

Museoalan Teemapäivät. (20I9). Retrieved November 8, 20I9 from www.museovirasto.f1

Pearce, S. (I990). Objects of Knowledge. London, UK: Athlone.

Pearce, S. (1992). Museums, Objects and Collections. A Cultural Study. Leicester, UK: Leicester University Press.

Piekkola, H., Suojanen, O., \& Vaino, A. (2013). Museoiden taloudellinen vaikuttavuus. Vaasa, Finland: Vaasan yliopisto Levón-instituutti.

Raworth, K. (2017). Doughnut Economy - Seven Ways to Think Like a $21^{\text {st }}$-Century Economist. London, UK: Penquin Random House.

Robbins, N. (2016). Poisto museokokoelmasta - Museologinen arvokeskustelu kokolemanhallinnan määrittäjänä. Jyväskylä Studies in Humanities 283. Jyva..skylä, Finland: University of Jyväskylä. 
Robbins, N. (2019a). Museological Value Discussion - A Tool to Transfer Tradition to the Future. In K. Smeds (Ed.), The Future of Tradition in Museology - Materials for discussion. (pp. I38-I42). Paris, France: ICOFOM.

Robbins, N. (2019b). Promoting Value Practice in Museums Creates Impact. Curator The Museum Journal. Wiley Online Library. (pp. I-I5). Retrieved December 23, 2019 from https://onlinelibrary.wiley.com/journal/21516952

Russell, R., \& Winkworth, K. (2009). Significance 2.o: A Guide to Assessing the Significance of Collections. Heritage Publications. Retrieved November 8 , 20Igfrom www.environment.gov.au/heritage/publications/significancez-o/part-I/index.html

Scott, C. (Ed.). (2013). Museums and Public Value. Burlington, US: Ashgate.

Simon, N. (2010). The Participatory Museum. Retrieved November 8, 2019 from

www.participatorymuseum.org/

Vaikuttavuusindikaattorit kulttuuripolitiikan tietopohjan vahvistajina. (2009). Opetusministeriön julkaisuja 2009: 57. Helsinki, Finland: Yliopistopaino. Retrieved November 8, 2019 from www.minedu.fi

Vilkuna, J. (1997). Comments on Outi Peisa,s Paper Presented at the Seminar: Stories of Museums. Ethnologia Fennica. Finnish Studies in Ethnology, 25, $57-6$ I

Vilkuna, J. (2003). Täytetyn tiikerin äärellä. Museologia, mitä se on? Retrieved December 20, 2013 from http://www.tieteessatapahtuu.fi/o37/vilkuna.pdf

Weil, S. (2002). Making Museums Matter. Washington, US: Smithsonian Books. 